\title{
頭頸部癌でのシスプラチン併用療法の効果
}

\author{
加納 有二・菊池 信幸・寺島 邦男
}

\section{Cisplatin Combined Chemotherapy for Head and Neck Cancer}

\author{
Yuji Kano, Nobuyuki Kikuchi and Kunio Terashima \\ (Teikyo University School of Medicine)
}

\begin{abstract}
The efficacy of cisplatin (CDDP) combined chemotherapy for stage III or $\mathrm{N}$ head and neck cancer was investigated. The response rate of cancers of the nasopharynx and oropharynx to $\mathrm{CDDP}+\mathrm{PEP}+\mathrm{MTX}$ therapy was high. In patients who received planned surgery after CDDP combined neoadjuvant chemotherapy and subsequent radiotherapy the three-year survival rate for patients with cancer of the oropharynx and hypopharynx was high (66.7\%). The aggressive introduction of CDDP combined chemotherapy is expected to improve the treatment of cancers of the pharynx, especially the oro- and nasopharynx. However, of the patients who received combined two or more courses of cisplatin-chemotherapy, 9 (30\%) stopped responding to the therapy during or after the second course. Countermeasures against the development of resistance to this therapy are therefore essential when it is to be given repeatedly.
\end{abstract}

Key words : CDDP combined chemotherapy, head and neck cancer, development of resistance

はじめに

頭頸部癌にたいする化学療法には, 進行癌や再発癌に たいする姑息的療法, 根治手術や根治照射後の再発や転 移の防止のための補助療法, 手術や放射線照射に先立ち 行われる導入化学療法 (induction chemotherapy あるい は neoadjuvant chemotherapy) がある。最近になり，放 射線照射との同時併用療法も積極的に検討され始めた ${ }^{1)}$. このうち補助療法を除く姑息的療法や導入化学療法には, 現在, シスプラチン (CDDP) を中心とした多剤併用療 法が行われることが多い1).

そこで, 今回, 帝京大学病院耳鼻咽喉科で頭頸部進行 癌(stage III, $\mathrm{N}$ 症例)にたいして, 過去 8 年間に姑息的 療法や導入化学療法あるいは放射線照射との併用療法と して行った CDDPを中心とした多剤併用療法の治療効 果を検討したので報告する。

\section{対象と方法}

対象は，1987年 5 月より1991年10月までに帝京大学病 院耳鼻咽喉科で入院加療した, 遠隔転移のないstage III, $\mathrm{N}$ の頭頸部癌症例のらち, シスプラチン併用化学療法 の施行例で 3 年以上の経過観察がでさた 45 症例とした. 内訳 (表 1 ) は, 上咽頭癌 8 例, 中咽頭癌 6 例, 下咽頭癌 13 例, 喉頭癌 3 例, 口腔癌 4 例, 鼻 - 副鼻腔癌 9 例, 唾液 腺癌 2 例である. 全症例中, 扁平上皮癌が39例, 腺癌 (唾 液腺癌 2 例, 上咽頭癌 2 例) が 4 例, 未分化癌 2 例 (上咽 頭癌 2 例)であった。このうち喉頭癌 3 例はともに放射 線照射と喉頭全摘出術後の局所再発例であり, 喉頭癌 3 例を除く42例はすべて新鮮例であった。

また, 年齢は14から77歳で, 平均58歳であり, performance status はすべて 2 以上であった.

対象とした新鮮症例42例のらち20例に導入化学療法を 施行した(表 2 ). 残りの 22 例に沶いては, 鼻・副鼻腔癌 全 9 例と口腔癌 1 例に拈いて照射と化学療法の同時併用 
表 1 対象症例の原発部位と病期分類 *喉頭癌 3 例はすべて照射と喉頭全摘 出術後の局所再発例である.

\begin{tabular}{|c|c|c|c|}
\hline 部位 & stage III & stage IV & 計 \\
\hline 上咽頭癌 & 5 & 3 & 8 \\
\hline 中咽頭凐 & 2 & 4 & 6 \\
\hline 下咽頭掂 & 7 & 6 & 13 \\
\hline 喉頭鸪 & 1 & 2 & $3 *$ \\
\hline 口㓐淮 & 2 & 2 & 4 \\
\hline 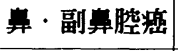 & 4 & 5 & 9 \\
\hline 唾液腺㵂 & 1 & 1 & 2 \\
\hline
\end{tabular}

療法を施行し, その他の12例(上咽頭癌全 8 例, 中咽頭 癌 1 例, 口腔癌 2 例, 唾液腺癌 1 例)に抽いては, 50 Gy 以上の照射後に化学療法を施行した(表 2 ).

今回の検討対象のらち喉頭癌 3 例を除く新鮮例 42 例に おいて, 根治治療にて腫瘍が消失し外来にて経過観察中 の再発例が10例あり, これら再発例に再度行った化学療 法は新たな化学療法例として加えた(表 2). 喉頭癌 3 例 を加えた再発例13例は化学療法のみを施行した。

Cisplatin (CDDP; Randa $\left.{ }^{\circledR}, 80 \mathrm{mg} / \mathrm{m}^{2}\right)$ と併用投与し た薬剤は, peplomycin (PEP; Pepleo ${ }^{\circledR}, 15 \mathrm{mg} /$ body 4 日間), methotrexate (MTX; Methotrexate ${ }^{\circledR}, 40 \mathrm{mg} /$ $\mathrm{m}^{2}$ ), Adriamycin 系の pirarubicin (THP-ADR ; Pinorubin $^{\circledR}, 50 \mathrm{mg} /$ body), cyclophosphamide (CPA ; Endo$\operatorname{xan}^{\circledR}, 200 \mathrm{mg} / \mathrm{m}^{2} 5$ 日間), fluorouracil (5-FU ${ }^{\circledR}, 1000$ $\mathrm{mg} / \mathrm{m}^{2} 5$ 日間)であった.
シスプラチンを中心とした併用療法の内訳では, $\mathrm{CDDP}+\mathrm{PEP}+\mathrm{MTX}$ が37例と多く, $\mathrm{CDDP}+\mathrm{PEP}$ が 8 例, CDDP + THP-ADR +CPA が 7 例, CDDP + 5-FU が 3 例であった. 原発部位と併用化学療法の種類を表 3 に示した.

化学療法の効果判定は, 日本頭頸部腫瘍学会の「頭頸 部がん治療効果判定基準」にもとづき判定した.すなわ ち化学療法の効果は, 著効 (CR), 有効 (PR), 不変 (NC), 扣よび進行 (PD) そ判定して, 著効 (CR) と有効 (PR) の みを奏効として奏効率を算出した。ただし，術前・照射 前に化学療法が行われた症例では，4 週間の経過観察を 行っていない症例もあった.

なお，今回対象としたすべてのシスプラチン併用化学 療法例に执いて，コロニ一刺激因子 (G-CSF や M-CSF) の併用投与は施行しなかった.

\section{結 果}

1 ） シスプラチン併用化学療法の効果判定

シスプラチン併用化学療法の効果判定をした奏効率を 表 4 に示した.

$\mathrm{CDDP}+\mathrm{PEP}+\mathrm{MTX}$ 併用療法 (37例) の奏効率は, 60 $\%$ (著効： $3 \%$, 有効 : $57 \%$ )であった。 このうち新鮮例 では奏効率74\%であり，再発例では20\%であった．著効 例は, stage III の上咽頭扁平上皮癌例であった。 CDDP $+\mathrm{PEP}+\mathrm{MTX}$ 併用療法の原発部位別の奏効率を表 5 飞 示した. 上咽頭癌の奏効率は $80 \%$, 中咽頭癌の奏効率は $71 \%$ (新鮮例 6 例のみでは $83 \%$ )で，上咽頭癌と中咽頭癌 の奏効率は高く, 下咽頭癌の奏効率は，57\%（新鮮例 10

表 2 シスプラチン併用療法例の原発部位別の内訳

\begin{tabular}{|c|c|c|c|c|c|}
\hline & \multicolumn{3}{|c|}{ 新鮮例 } & \multirow[b]{2}{*}{ 再発例 } & \multirow[b]{2}{*}{$\begin{array}{c}\text { 経過中の } \\
\text { 再発例 }\end{array}$} \\
\hline & $\begin{array}{c}\text { 導入化学 } \\
\text { 療法例 }\end{array}$ & $\begin{array}{l}\text { 照射と同 } \\
\text { 時併用例 }\end{array}$ & $\begin{array}{c}\text { 照射後の } \\
\text { 併用例 }\end{array}$ & & \\
\hline 上咽頭癌 & 0 & 0 & 8 & 0 & 0 \\
\hline 中咽頭癌 & 5 & 0 & 1 & 0 & 1 \\
\hline 下咽頭癌 & 13 & 0 & 0 & 0 & 4 \\
\hline 喉頭洊 & 0 & 0 & 0 & 3 & 0 \\
\hline 口腔癌 & 1 & 1 & 2 & 0 & 1 \\
\hline 臭·副算案癌 & 0 & 9 & 0 & 0 & 3 \\
\hline 唾液腺浩 & 1 & 0 & 1 & 0 & 1 \\
\hline 合計 & 20 & 10 & 12 & 3 & 10 \\
\hline
\end{tabular}


表 3 各シスプラチン併用療法の原発部位別の症例数

（ ）内は再発症例数である.

\begin{tabular}{|c|c|c|c|c|}
\hline & $\begin{array}{c}\text { CDDP+PEP } \\
+ \text { MTX }\end{array}$ & $\mathrm{CDDP}+\mathrm{PEP}$ & $\mid \begin{array}{c}\mathrm{CDDP}+\mathrm{THP}-\mathrm{A} \\
\mathrm{DR}+\mathrm{CPA}\end{array}$ & $\mathrm{CDDP}+5-\mathrm{FU}$ \\
\hline 上咽頭㵂 & 5 & 0 & 3 & 0 \\
\hline 中咽頭淲 & 7 (1) & 0 & 0 & 0 \\
\hline 下咽頭䍄 & $14(4)$ & 2 & 1 & 0 \\
\hline 喉頭湾 & (2) & 0 & (1) & 0 \\
\hline 口腔痁 & 3 & 0 & 0 & $2(1)$ \\
\hline 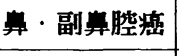 & $5 \quad(3)$ & 6 & 0 & 1 \\
\hline 唾液腺掂 & 1 & 0 & $2(1)$ & 0 \\
\hline 合計 & $37\left(\begin{array}{ll}1 & 0\end{array}\right)$ & 8 & $7(2)$ & $3(1)$ \\
\hline
\end{tabular}

例の奏効率は $67 \%$ )であった. 口腔癌は 3 例と少数であ ったが全例において有効であった，鼻・副鼻腔癌の奏効 率は17\%で，このうち新鮮例の奏効率は $50 \%$ であり, 再 発例はすべて不変であった. 照射と喉頭全摘出術後の局 所再発例である喉頭癌 2 例は 2 例とも不变であった. 上 咽頭・中咽頭癌および口腔癌の奏効率が他の部位の奏効 率に比べて高率であった。

CDDP +PEP 併用化学療法 ( 8 例) では, その奏効率

表 4 シスプラチン併用療法別の 治療効果

\begin{tabular}{c|c}
\hline \hline 併用療法 & 奏効率 $(\%)$ \\
\hline CDDP+PEP+MTX & 60 \\
\hline CDDP+PEP & 63 \\
\hline CDDP+THP-ADR+CPA & 57 \\
\hline CDDP+5-FU & 33
\end{tabular}

表 $5 \mathrm{CDDP}+\mathrm{PEP}+\mathrm{MTX}$ 併用療法の 原発部位別の治療効果

\begin{tabular}{|c|c|}
\hline 原発部位（例数） & 奏效率 (\%) \\
\hline 上咽頭腑（5） & 80 \\
\hline 中咽頭癌（7） & 71 \\
\hline 下咽頭㵂（1 4) & 57 \\
\hline 喉頭癌（2） & 0 \\
\hline 口㬶癌（3） & 100 \\
\hline 臭·副算嘋癌 (5) & 17 \\
\hline
\end{tabular}

は63\%で，有効例の 5 例はすべて副鼻腔癌の動注療法例 であった.

$\mathrm{CDDP}+\mathrm{THP}-\mathrm{ADR}+\mathrm{CPA}$ 併用化学療法 $(7$ 例) の奏 効率は $57 \%$ で, 著効を認めた 2 症例はともに上咽頭癌(未 分化癌と末分化腺癌)であった. CDDP+THP-ADR+ $\mathrm{CPA}$ 併用化学療法に括いても上咽頭癌の奏効率は良好 であった．全上咽頭癌に护けるシスプラチン併用化学療 法の奏効率は，75\%であった。

$\mathrm{CDDP}+5-\mathrm{FU}$ 併用化学療法 ( 3 例) の奏効率は $33 \%$ で あった。

また，シスプラチン併用化学療法を 2 クール以上反復 した30例のらち，1クール目は有効以上(著効と有効)で あったものの 2 クール目以降に無効(不変と進行)となっ た症例が，9例(30\%)であった。

2 ）導入化学療法

導入化学療法としてシスプラチン併用化学療法を20例 (中咽頭癌 5 例, 下咽頭癌 13 例, 口腔癌 1 例, 唾液腺癌 1 例)に施行した。 その結果は，奏効率 $65 \%$ であった. このうち CDDP+PEP+MTX 併用化学療法 (18例) の奏 効率が72\% (13例すべて有効)で, 残りの CDDP+PEP 併用化学療法を施行した 2 例はともに不変であった. 中 咽頭癌の奏効率は $60 \%$ ( 3 例), 下咽頭癌の奏効率は 62 \%(8例)であった.

導入化学療法の後続治療は, 放射線照射治療 (40 Gy) 後に予定の手術を施行したもの 12 例 (中咽頭癌 3 例, 下 咽頭癌 9 例), 放射線照射治療を施行したもの 4 例 (中咽 頭癌 1 例, 下咽頭癌 3 例) であった。化学療法のみのも の 4 例 (中咽頭癌 1 例, 下咽頭癌 1 例, 口腔癌 1 例, 唾 
液腺癌 1 例) であった.

3 ) 副作用と予後

重篤な副作用としては, 白血球減少による肺炎と DIC の併発例および血小板减少による肺胞内出血例の 2 例の死亡例 ( 2 例とも舌癌再発症例) があった.

3 年生存率は, CDDP + PEP + MTX 併用療法が 29 $\%$ (生存 9 例で, 内訳は上咽頭癌 5 例中 1 例 $20 \%$, 中咽 頭癌 7 例中 2 例 $29 \%$, 下咽頭癌 14 例中 6 例 $43 \%$ であっ た.），CDDP+PEP 併用療法が $25 \%$ (上䫁癌 6 例中の 2 例)，CDDP+THP-ADR+CPA 併用療法が $29 \%$ (上咽 頭癌 4 例中の 2 例), CDDP +5-FU 併用療法が $33 \%$ (口 腔癌 2 例中の 1 例)であった。著効のためにそのまま経 過観察をしたものは上咽頭癌 3 例で，これら 3 例はとも に 5 年以上経過する現在も再発は認めていない。な报,

再発症例では 3 年以上の生存例はなかった.

導入化学療法の後続治療終了後の予後は, 放射線照射 治療 $(40 \mathrm{~Gy})$ 後に予定の手術を施行したもの (12例；中 咽頭癌 3 例, 下咽頭癌 9 例) では, 3 年以上生存例が 67 $\%$ ( 8 例; 中咽頭癌 2 例と下咽頭癌 6 例) であった. 放射 線照射治療を施行したもの 4 例 (中咽頭癌 1 例, 下咽頭 癌 3 例) と化学療法のみのもの 4 例 (中咽頭癌 1 例, 下咽 頭癌 1 例, 口腔癌 1 例, 唾液腺癌 1 例) では, 3 年以上 の生存例はなかった。

\section{考察}

従来の頭頸部癌の化学療法は, 進行癌や再発癌にたい する姑息的療法が主体であったが，近年，手術や放射線 照射に先立ち行われる導入化学療法や根治手術や根治照 射後の再発や転移の防止のための補助療法が，積極的に 検討されている1)。

\section{1）多剂併用療法}

頭頸部癌にたいする化学療法としては，1960年代に cyclophosphamide (CPA) や 5-fluorouracil (5-FU) や bleomycin (BLM) などが主に動注化学療法に用いられ始め た1).1970年代になると cisplatin (CDDP) が出現し，頭 頸部癌に対する化学療法の成績が飛躍的に向上した1). ところが, これら抗癌剤の単独投与では, 癌の根治を得 られないことが明らかにされ1)，これら抗癌剤の併用投 与が頭頸部癌に臨床応用されるようになった.

頭頸部癌を対象とした抗癌阂の多剤併用投与について

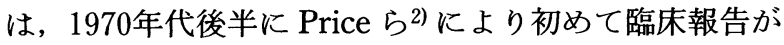
なされた．1979年 Hong ら3)が CDDP とブレオマイシ
ソ (BLM) の併用投与を放射線照射や手術に先立ち施行 する導入化学療法 (induction chemotherapy) として報告 し，化学療法を放射線照射や手術に先立ち施行するとい ら考党が普及し始めた。ささらに，1982年に Frei III) より初めて化学療法を放射線照射や手術に先立ち施行す る方法にたいして neo-adjuvant chemotherapy (NAC) と 言う言葉が用いられ，現在頻用されている. 同年に Kish ら5)の neo-adjuvant chemotherapy としての CDDP と 5-FU の併用化学療法の成績が報告され, neo-adjuvant chemotherapy が盛んに行われるようになった11677).

わが国では1983年に全国規模でCDDPとMTX と PEP あるいは BLM の 3 剂の無作為化比較試験が行わ れ，1987年にその結果が報告され8)，現在も多剤併用療 法の効果的な投与法の検討がなされている1). 今回われ われが1987年より行ったCDDP と他の抗癌剤を併用し た化学療法は, 全国規模で無作為化比較試験が行われた CDDP と PEP と MTX の併用療法をもとに施行し, 腺 癌には木田ら ${ }^{9)}$ の報告の CDDP と THP-ADR と CPA の併用療法 (CAP 療法) を用い, 副鼻腔癌には Inuyama ら ${ }^{10)}$ の報告の CDDP と PEP の併用療法をもとに行っ た結果である.

佐竹ら ${ }^{8)}$ の頭頸部癌の stage III と N を対象とした, 全国規模で無作為化比較試験が行われた CDDP と PEP と MTX の併用療法の結果の報告では，66例中奏効率 $51.5 \%$ であった. 今回のわれわれの成績では, CDDP+ $\mathrm{PEP}+\mathrm{MTX}$ 併用療法 (37例)の奏効率は $60 \%$ (新鮮例で は74\%) と比較的良好の結果であった. CDDP と THP$\mathrm{ADR}$ と CPA の併用療法(CAP 療法)について木田ら 9 ) の報告では奏効率 $53 \%$ であり，われわれの成績では THP-ADR ADR の代わりに併用使用した結果, 著効 2 例で奏効率は $57 \%$ と良好の結果であった。CDDP と PEP の併用療法について犬山ら $68.2 \%$ であり，われわれの成績では奏効率 $63 \%$ であった。 また, 犬山ら ${ }^{111}$ の CDDP と PEP の併用療法について の頭頸部癌の stage III と N を対象とした無作為化比較

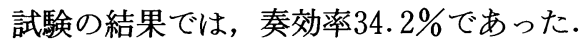

上咽頭癌にたいしては化学療法の導入により生存率が 向上していることが報告されている12). 上咽頭癌につい ての今回のわれわれの成績は, 照射後に行った全身化学 療法の結果で 3 年生存率 $38 \%$ であり, 犬山 ${ }^{12)}$ による照 射の併用あるいは照射後の全身化学療法による 5 年確定 生存率の報告 $37 \%$ とほ湾同率であった。さらに犬山 ${ }^{12)}$ 
の報告によると，導入化学療法を組み入れた集学的治療 で， 5 年確定生存率が $44 \%$ とより良好な成績を上げて括 り, 上咽頭癌にたいしても積極的な導入化学療法が望ま れると考えられる．なお，われわれの成績では無作為化 比較試験をしていないものの, 中咽頭癌に打いても良好 な結果であった。

\section{2 ) 導入化学療法}

近年, 導入化学療法が精力的に行われている，導入化 学療法の目的として藤井ら ${ }^{6)}$ は， 1) 化学療法により腫 瘍を減量して手術や照射などの局所療法をより有効にす る，2 ) 切除不能症例を切除可能にする， 3 ) 微小転移巣 を根絶して遠隔転移を防止する，としており，最終的に は, 非再発生存率 (disease free survival) の向上を目指 すものとしている.

導入化学療法の奏効率については，60\%から90\%の非 常に良好な結果が得られているが6)，無作為化比較試験 (randomized study)の結果では, 導入化学療法による生 存期間あるいは遠隔成績の改善は認められて抢らず，さ まざまな問題点があげられている677)。ただ，中咽頭癌 にたいする導入化学療法は良好な成績が得られて和り， われわれの成績でも同様に良好であった。 また，今回の われわれの成績では， 3 年生存率ではあるが下咽頭癌に おいても良好な成績を得ている，導入療法の遠隔転移の 防止については，その評価がむずかしいものの，当初期 待されたほどの満足すべき結果は得られていない667112).

3 ) 薬剤耐性

今回のわれわれの成績では, シスプラチン併用化学療 法を 2 クール以上反復した 30 例のらち，9例(30\%)に拉 いて 1 クール目は有効以上(著効と有効)であったものの 2 クール目以降に無効(不変と進行) となった. 今回の検 討で示されたように，シスプラチンをすでに投与されて これに反応しなくなった症例，すなわち薬剤耐性が大き な臨床上の課題となっている。

甲能 ${ }^{13)}$ は, 薬剤耐性についてその抵抗性には, 単一 細胞レベル (single cell level) での耐性因子と固形癌の腫 瘍塊レベルでの耐性因子があり，これらの因子の相互作 用で，臨床上の薬剂耐性が成り立っていると述べている。 固形癌の腫瘍塊としての耐性因子には，1)腫瘍塊の大 きさが増加して細胞の密度が高くなると薬剤の効果が低 くなること (inoculum effect), 2) 薬剤の深達性 (penetration), 3 ) 腫瘍塊としての耐性細胞の増加 (development of drug resistant mutant cell), 4 )腫瘍塊中心部の低酸
素や低栄養状態 (sanction) があると述べている．またさ らに, CDDP 抵抗癌に対する療法として, CDDP+VP$16+\mathrm{MMC}$ の 3 剤の併用療法执よび少量 CDDP+5-FU の長期投与を提唱している13)。著者らは，CDDP 抵抗 癌にたいする化学療法として, 現在, CDDP or carboplatin (CBDCA) +VP-16の 2 剂の併用療法と少量 $\mathrm{CDDP}+5-\mathrm{FU}$ の長期投与を施行して括り，良好な成績 である ${ }^{14)}$. CDDP と交差耐性がなくCDDP 抵抗癌に効 果のできる開発中の抗癌剤として, Taxol や Taxotere や 254-S (CDDP 誘導体) などがあり検討されている1315).

多剤併用療法の副作用については, 現在, コロニ一刺 激因子の併用と制吐剤の併用により著明にその程度が改 善しており 1617)，化学療法の QOL の改善に寄与してい る. 血小板の減少にたいする増殖因子の早期の臨床応用 が待たれる。

近年, 新しい薬剤の開発と積極的な導入化学療法の試 みや多剤併用による効果的な投与法の検討がなされてい る. それとともに，放射線と化学療法の同時併用 18119 ) や積極的な補助化学療法 20) や免疫療法を積極的に併用 した免疫化学療法 (immunochemotherapy) ${ }^{21)}$ が精力的に 試みられている。

\section{まとめ}

頭頸部進行癌にたいして行った CDDP を中心とした 併用療法の治療効果を検討した。 その結果, 上咽頭癌・ 中咽頭癌に打いては，CDDP $+\mathrm{PEP}+\mathrm{MTX}$ の多剤併用 療法の奏効率が良好であった．導入化学療法としては， その後続治療として放射線照射治療後に予定の手術を施 行した中咽頭癌例，下咽頭癌例では， 3 年以上生存率が $67 \%$ と良好であった，咽頭癌とくに上咽頭扣よび中咽頭 癌では, シスプラチン併用化学療法の積極的な導入によ り, 治療効果の向上が期待されると考兄られた. シスプ ラチン併用化学療法を反復した例では 2 クール目以降に 無効となった症例が 9 例 (30\%) に認められ，これら薬剤 耐性の獲得例にたいする対策が，シスプラチン併用化学 療法を反復して行ら場合に必要であると考えられた。

本報告の要旨は, 第17回日本頭頸部腫瘍学会にて発表した.

\section{引用文献}

1) 犬山征夫：頭頸部癌化学療法の歴史と現況. JOHNS 9:9 $\sim 16,1993$. 
2 ) Price LA, Hill B, Macrae K, et al : Integration of safe initial combination chemotherapy (without cisplatin) with a high response rate and local therapy by untreated stage III and $\mathrm{N}$ epidermoid cancer of the head and neck ; 5-year survival data. Cancer Treat Rep 67 : 535 539, 1983.

3 ) Hong W, Stanley M, Shapner $M$, et al : Induction chemotherapy in advanced squamous head and neck carcinoma with high dose cisplatinum and bleomuycin infusion. Cancer $44: 19 \sim 25,1979$.

4) Frei III E : Clinical cancer research; an embattled species. Cancer $50: 1979 \sim 1992,1982$.

5 ) Kish J, Drelichman A, Jacobs J, et al : Clinical trials of cisoplatin and 5-FU infusion as initial treatment of advanced squamous cell carcinoma of the head and neck. Cancer Treat Rep $66: 471 \sim 474,1982$.

6 ）藤井正人, 川崎和子 : 頭頸部癌に対する化学療法 - Neoadjuvant Chemotherapy一. 癌と化学療法 18 : 2083〜2089, 1991.

7 ) 安田範夫: 頭頸部癌の neoadjuvant chemotherapy. JOHNS $4: 40 \sim 44,1993$.

8 ）佐竹文介, 松浦 鎮, 金子省三, 他 : 頭頸部がん進展例に 対する多剂併用療法 (CDDP, Bleomycin 類, Methotrexate) の治療効果. 耳鼻臨床 $80: 941 \sim 950,1987$.

9 ）木田亮紀, 青柳充雄, 川村 繁, 他 : 頭頸部の腺癌, 腺様 襄胞癌の化学療法 一CAP 療法の一次的効果とその評価方 法一. 耳鼻 $32: 612 \sim 617,1986$.

10) Imuyama $Y$, Fujii $M$, Tanaka $J$, et al : Neoadjuvant chemotherapy in maxillary sinus carcinoma with cisplatinum and peplomycin intraarterial infusion. Auris Nasus Larynx $12:$ S249 S254, 1985.

11）犬山征夫, 戸川 清, 高坂知節, 他 : 頭頸部進行扁平上皮 癌に対する Carboplatin + PEP 療法と CDDP + PEP 療法の
無作為化比較試験. 耳鼻 $34: 1511 \sim 1519,1988$.

12）犬山征夫：頭頸部癌に対する neoadjuvant chemotherapy. 耳鼻臨床 $82: 1043 \sim 1050,1989$.

13）甲能直幸：シスプラチン抵抗癌に対する治療. JOHNS 4 : 45〜 49, 1993.

14）坂田英明, 安達忠治, 角田浩幸, 他: 多剤併用療法に抵抗 を示した症例に対するシスプラチンあるいはカルボプラチ ンとエトポシドの治療効果. 第18回日本頭頸部腫瘍学会予 稿集. 314頁, 1994.

15）犬山征夫, 佐藤公輝, 古田 康, 他: シスプラチン耐性癌 への対応. JOHNS $7:$ 597〜602, 1991.

16）斉藤匡人, 田端敏秀: 癌化学療法の副作用とその対策. JOHNS 4 : 105 109, 1993.

17）橋本循一, 角田浩幸, 加納有二 : 頭頸部悪性腫瘍に対する 顆粒球コロ $=$-刺激因子 (G-CSF) の効果的な投与法の検 討 -1 回皮下投与と 24 時間持続皮下投与との比較一. 第 18回日本頭頸部腫瘍学会予稿集. 287頁, 1994.

18）福田 論, 犬山征夫, 栗原秀雄, 他 : 頭頸部癌に対する Neoadjuvant therapy -Carboplatin と放射線の同時併用 一. 日癌治 $27: 1261,1992$.

19）佐竹文介, 中川雅裕, 宇留間哲也, 他 : 頭頸部癌の放射線 治療と化学療法の同時併用療法. JOHNS 4 : 85 88, 1993.

20）堀内正敏, 三宅浩郷：頭頸部癌の adjuvant chemotherapy. JOHNS $4: 33 \sim 39,1993$.

21）松岡浩明, 石川 哮: 免疫化学療法. JOHNS $4: 79 \sim 84$, 1993.

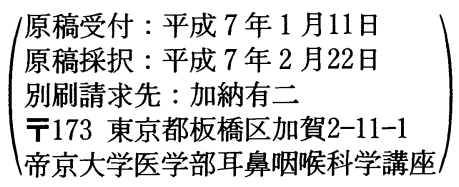

